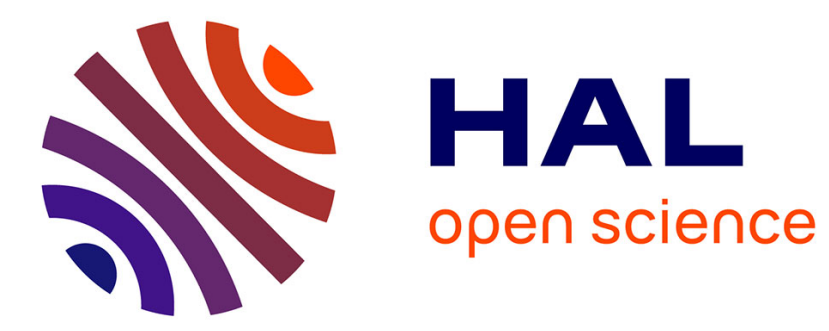

\title{
Phosphorus-based chromophores: Emitters for OLEDs
}

Matthew P. Duffy, Pierre-Antoine Bouit, Bernard Geffroy, Denis Tondelier, Muriel Hissler

\section{To cite this version:}

Matthew P. Duffy, Pierre-Antoine Bouit, Bernard Geffroy, Denis Tondelier, Muriel Hissler. Phosphorus-based chromophores: Emitters for OLEDs. Phosphorus, Sulfur, and Silicon and the Related Elements, 2015, 190 (5-6), pp.845-853. 10.1080/10426507.2014.980414 . hal-01100663

\section{HAL Id: hal-01100663 https://hal-univ-rennes1.archives-ouvertes.fr/hal-01100663}

Submitted on 23 May 2016

HAL is a multi-disciplinary open access archive for the deposit and dissemination of scientific research documents, whether they are published or not. The documents may come from teaching and research institutions in France or abroad, or from public or private research centers.
L'archive ouverte pluridisciplinaire HAL, est destinée au dépôt et à la diffusion de documents scientifiques de niveau recherche, publiés ou non, émanant des établissements d'enseignement et de recherche français ou étrangers, des laboratoires publics ou privés. 


\title{
Phosphorus-based chromophores: Emitters for OLEDs
}

\author{
Matthew P. Duffy, ${ }^{1}$ Pierre-Antoine Bouit, ${ }^{1}$ Bernard Geffroy, ${ }^{2}$ Denis Tondelier, ${ }^{3}$ and Muriel Hissler ${ }^{*}, 1$ \\ ${ }^{1}$ Institut des Sciences Chimiques de Rennes, UMR 622, CNRS-Université de Rennes 1, \\ Campus de Beaulieu, 35042 Rennes cedex \\ ${ }^{2}$ Laboratoire d'Innovation en Chimie des Surfaces et Nanosciences, CEA Saclay, IRAMIS, \\ NIMBE, IRAMIS, SPCSI, 91191 Gif-sur-Yvette, France \\ ${ }^{3}$ Laboratoire de Physique des Interfaces et Couches Minces, CNRS UMR 7647, Ecole \\ Polytechnique, 91128 Palaiseau, France
}

\section{muriel.hissler@univ-rennes1.fr}

\begin{abstract}
In this paper, we present the development of white OLEDs (WOLEDs) using organophosphorus derivatives as fluorescent emitters. The structural changes that we have performed on and around the phosphole ring (functionalization of the phosphorus atom, nature of the substituents at the 2 and 5 position) allow the ability to tune the emission wavelengths and the color emitted by the OLEDs. Using this concept, we developed organophosphorus dopants emitting orange light, which can be mixed with a blue emitting matrix for the development of WOLEDs. The OLEDs structure allows the development of flexible OLEDs with good performance and CIE coordinates which are independent from the current density.
\end{abstract}

Keywords Phosphole, $\pi$-conjugated systems, WOLEDs, optoelectronics

\section{INTRODUCTION}

The development of technologies based on molecular electronics (field-effect transistors (OFET), light-emitting diodes (OLED), solar cells ...) was accompanied by a strong development of the synthesis and photo-physical studies of organic and organometallic compounds having an extended $\pi$-conjugated system.[1] Indeed, the development of efficient "plastic electronic" devices is only possible with control of electronic properties and macroscopic organization of these active compounds. A great deal of attention has therefore been focused on tuning the structure of the organic $\pi$-conjugated materials in order to control their electronic nature (band gap, HOMO and LUMO levels, effective conjugation length, etc.) in such a way that it suits the desired function (electroluminescence, high charge mobility, etc.). In this perspective, oligomers and $\pi$-linear conjugated polymers incorporating heteroatoms have received special attention.[1,2] The incorporation of heterocyclopentadienes 
(thiophene, pyrrole, silole...) allows the emergence of new geometric and electronic properties directly related to the nature of the heteroelement.[3] In this context, the phosphole ring is an attractive synthon since it displays electronic properties that are markedly different from those of the widely used highly aromatic thiophene and pyrrole rings.[4] The key property of the phosphole ring for the molecular engineering of $\pi$-conjugated systems is the presence of a reactive phosphorus center due to the low aromatic character of this P-heterole. In fact, delocalization within the phosphole ring arises from a hyperconjugation involving the exocyclic P-R $\sigma$-bond and the $\pi$-system of the dienic moiety leading to $\sigma-\pi$ hyperconjugation phenomenon.[4] The insertion of this P-heterocycle within classical $\pi$-conjugated systems results in a lowering of their HOMO-LUMO gaps [5c-e] since conjugation is enhanced for macromolecules incorporating units exhibiting low resonance energies. Moreover, the phosphole building block is a potential source of further structural variations by $(i)$ changing the nature of the P-substituent, (ii) chemical modifications of the nucleophilic P-atom, (iii) using this P-ring as a precursor to other P-heterocycles featuring a $\pi$-system such as phosphametallocenes or (iv) inserting the phosphole into a 2D graphenic scaffold (Figure 1).[6] These properties indicate that the phosphole is a good candidate for the construction of tuneable emissive $\pi$-conjugated systems.
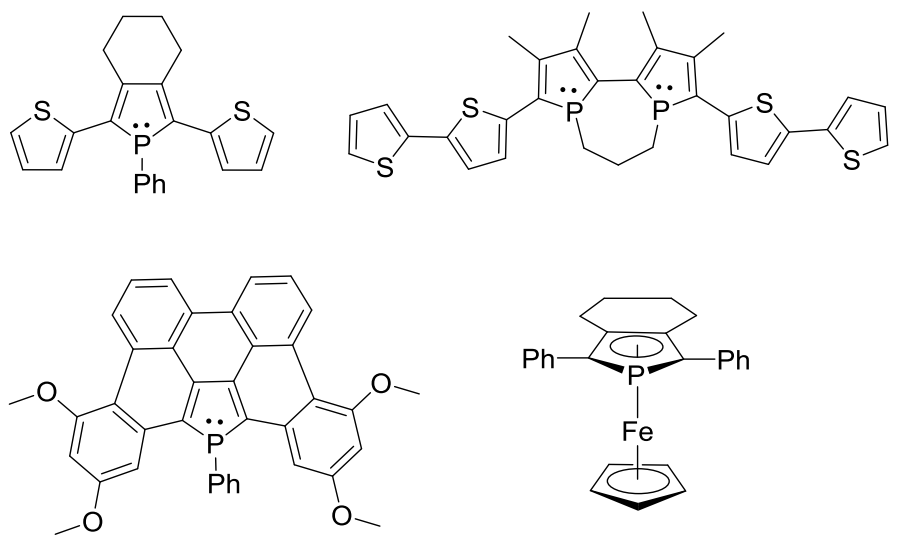

Figure 1: Example of phosphole based $\pi$-conjugated systems

\section{RESULT AND DISCUSSION}

The introduction of phosphole building blocks in $\pi$-conjugated systems allows the ability to perform molecular engineering of these $\pi$-systems using the power of phosphorus chemistry. Simple chemical modifications performed on the phosphorus atom (oxidation, coordination chemistry...) allows straightforward access to a wide range of novel $\pi$ - 
conjugated systems with diverse optical and electrochemical properties, without the need for additional multi-step syntheses.[5c,d;6] This strategy allowed us to optimize the emission properties of the organophosphorus chromophores for the development of electroluminescent diodes emitting different colors (yellow, orange...).[6a-c,h] The performances of these diodes are notable for fluorescent compounds. Following this work, we decided to use our expertise to develop a novel series of orange-emitting dopants incorporating a phosphole ring for the development of white OLEDs (WOLEDs). The use of the Fagan-Nugent conditions on the dialkynes 1a,b to generate the phosphole, followed by oxidation with $\mathrm{S}_{8}$ afforded thioxophospholes 2a,b (Scheme 1).[5c] These air stable compounds display ${ }^{31} \mathrm{P}$ NMR chemical shifts in the usual range of thioxophopholes $(\mathbf{2 a}:+51.6, \mathbf{2 b}:+52.5 \mathrm{ppm})$ and all their ${ }^{1} \mathrm{H}$ and ${ }^{13} \mathrm{C}$ NMR spectroscopic data support the proposed structures.

$$
\begin{aligned}
& \text { 1a,b } \\
& \text { a: } \mathrm{R}=\mathrm{R}^{\prime}=\text { 5-methyl-thien-2-yl } \\
& \text { b: } \mathrm{R}=\text { 9,9-(dimethyl)-fluoren-2-yl, } \mathrm{R}^{\prime}=\text { 5-methylthien-2-yl }
\end{aligned}
$$

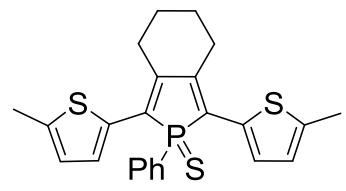

$2 a$

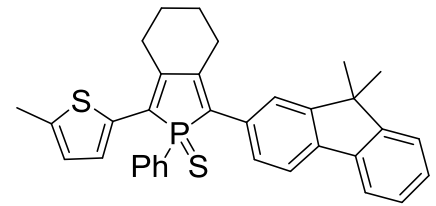

$2 b$

Scheme 1. Synthetic routes to phosphole-based dopants

Table 1. Optical (solution and in thin films) and electrochemical properties for the organophosphorus compounds $\mathbf{2 a}, \mathbf{b}$.

\begin{tabular}{cccccccccc} 
Compound & $\begin{array}{c}\lambda_{\max } \\
{[\mathrm{nm}][\mathrm{a}]}\end{array}$ & $\begin{array}{c}\varepsilon \\
{\left[\mathrm{mol}^{-1} . \mathrm{L.cm}\right.} \\
\left.{ }_{1}\right]\end{array}$ & $\begin{array}{c}\lambda_{\mathrm{em}} \\
{[\mathrm{nm}][\mathrm{a}]}\end{array}$ & $\begin{array}{c}\Phi_{\mathrm{f}} \\
(\%)[\mathrm{b}]\end{array}$ & $\begin{array}{c}\lambda_{\mathrm{em}} \\
{[\mathrm{nm}]} \\
{[\mathrm{c}]}\end{array}$ & $\begin{array}{c}\phi_{\mathrm{f}} \\
{[\%][\mathrm{d}]}\end{array}$ & $\begin{array}{c}E_{o x}^{1} \\
{[\mathrm{~V}][\mathrm{e}]}\end{array}$ & $\begin{array}{c}E_{o x}^{2} \\
{[\mathrm{~V}][\mathrm{e}]}\end{array}$ & $\begin{array}{c}E_{\text {red }}^{1} \\
{[\mathrm{~V}][\mathrm{e}]}\end{array}$ \\
\hline $\mathbf{2 a}$ & 447 & 29320 & 575 & 0.5 & 549 & 70 & +0.95 & +1.28 & -1.61 \\
\hline $\mathbf{2 b}$ & 420 & 14400 & 578 & 0.5 & 560 & 55 & +1.13 & +1.36 & -1.61
\end{tabular}

[a] Measured in $\mathrm{CH}_{2} \mathrm{Cl}_{2}$. [b] Fluorescence quantum yields determined using fluoresceine as standard, $\pm 15 \%$. [c] Dispersed in PMMA (2 wt.\%.). [d] Measured in an integrating sphere. [e] All potentials were obtained during cyclic voltammetric investigations in $0.2 \mathrm{M} \mathrm{Bu}_{4} \mathrm{NPF}_{6}$ in $\mathrm{CH}_{2} \mathrm{Cl}_{2}$. Platinum electrode diameter $1 \mathrm{~mm}$, sweep rate: $200 \mathrm{mV} \mathrm{s}^{-1}$. All reported potentials are referenced to SCE.

Optical properties of $\mathbf{2 a}, \mathbf{b}$ were studied in $\mathrm{CH}_{2} \mathrm{Cl}_{2}$ and in thin films by means of UV-Vis absorption and fluorescence (Table 1). The two compounds show broad absorption in the visible range (Table 1), attributed to $\pi-\pi^{*}$ transitions of the extended conjugated system, and 
a broad emission in the orange region of the visible spectrum. The replacement of the methylthiophene substituent by a fluorenyl group doesn't dramatically modify the physical properties. The maximum of absorption is blue shifted, the emission is weakly affected $\left(\mathbf{2 b} / \mathbf{2 a} ; \Delta \lambda_{\max }=27 \mathrm{~nm}, \Delta \lambda_{\mathrm{em}}=3 \mathrm{~nm}\right.$, Table 1) and the photoluminescence (PL) quantum yields (QYs) in solution are low. It was of interest to investigate their PL property in a polymethylmethacrylate (PMMA) matrix since these compounds are used as solid state emitters in OLEDs. The maxima of emission in PMMA (doping rate, 2 wt.\%) are only slightly blue-shifted compared to those recorded in solution (Table 1) and the PL QYs of $\mathbf{2 a}, \mathbf{b}$ in PMMA matrix reach 55-70\%, values that are considerably higher than those observed in solution (Table 1). These observations, which are very appealing towards the development of phosphole derivatives 2a,b as emitters for OLEDs, can be attributed to rotational restriction in the solid state and to steric protection provided by the tetrahedral P-center, the endocyclic cyclohexane, and the bulkiness of the fluorene and methylthiophene substituent of compounds $\mathbf{2 a , b}$ preventing the formation of organized stacks in the solid state.[6c,h]

The redox properties of these novel phosphole-based $\pi$-conjugated systems $\mathbf{2 a}$,b were determined by cyclic voltammetry $(\mathrm{CV})$ and recorded in $\mathrm{CH}_{2} \mathrm{Cl}_{2}$ using $\mathrm{Bu}_{4} \mathrm{NPF}_{6}$ as the electrolyte. The compounds $\mathbf{2 a}, \mathbf{b}$ present reversible reduction and oxidation processes. Furthermore, the nature of the substituents in position 2 and 5 on the phosphole ring affects the oxidation potentials while the reduction potentials are not modified (Table 1). The LUMO level is unchanged and the HOMO level is stabilized going from compound $\mathbf{2 a}$ to $\mathbf{2 b}$ since molecule 2a (Scheme 1) presents a lower oxidation potential than compound $\mathbf{2 b}$ (Table 1).

Since compounds $\mathbf{2 a}, \mathbf{b}$ are redox and thermally stable up to $300^{\circ} \mathrm{C}$ and present an orange emission (Table 1), we decided to co-evaporate them with a blue emitter, 4,4'-bis(2,2'diphenylvinyl)biphenyl (DPVBi) for the construction of the active layer in WOLEDs. Effectively, white emission could potentially be obtained by combining orange and blue emissions if the ratio of the two colours is correct.[7] First, we developed a multilayer WOLED on a glass substrate having an (ITO/CuPc $(10 \mathrm{~nm}) / \alpha-\mathrm{NPB}(50 \mathrm{~nm}) /$ doped-DPVBi $(50 \mathrm{~nm}) / \mathrm{Alq}_{3}(10 \mathrm{~nm}) / \mathrm{LiF}(1.2 \mathrm{~nm}) / \mathrm{Al}(100 \mathrm{~nm})$ structure. Doping of the blue matrix with $0.2 \%$ of compound $2 \mathbf{a}$ lead to an OLED exhibiting a small turn-on voltage (5.2V) with current and power efficiencies of $7.0 \mathrm{~cd} \mathrm{~A}^{-1}$ and $2.3 \mathrm{~lm} / \mathrm{W}$, respectively. Its electroluminescent spectrum presents well-balanced emission characteristics of the DPVBi $(452 \mathrm{~nm}, \mathrm{FWHM}=$ $70 \mathrm{~nm})$ and of the dopant 2a $(548 \mathrm{~nm}, \mathrm{FWHM}=115 \mathrm{~nm})$ (Figure 2). The resulting CIE coordinates of device $\mathbf{A}(0.31 ; 0.39)$ are close to those of pure white-light $(0.33,0.33)$ (Table 2$)$ 
and are independent of the driving current. These data show that phosphole-based small molecules can be used as dopants for DPVBi towards the development of efficient WOLEDs. However, the required low doping rate value $(c a .0 .2 \%)$ to reach white emission is quite difficult to control and to reproduce within the co-evaporation process.

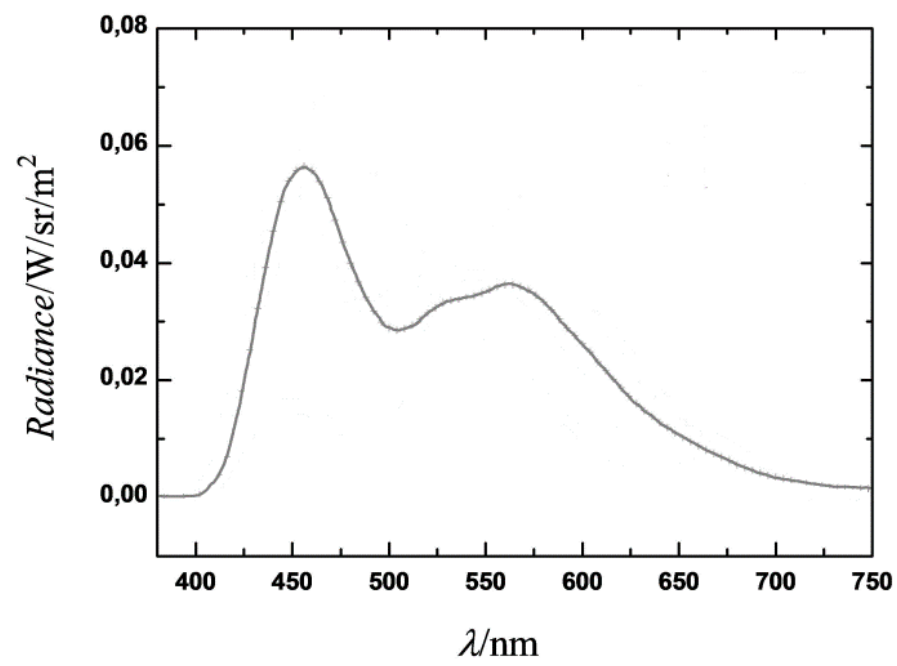

Figure 2: EL spectra of the device A recorded at $30 \mathrm{~mA} / \mathrm{cm}^{2}$

Table 2. El performance of devices as function of the device structure and the doping rate

\begin{tabular}{|c|c|c|c|c|c|c|c|}
\hline \multirow[t]{2}{*}{ Device } & $\begin{array}{c}\text { Doped layer; } \\
\text { dopant }^{\mathrm{a}}\end{array}$ & $\lambda_{\max }^{\mathrm{EL}}$ & $\begin{array}{c}\text { Turn- } \\
\text { on } \\
\text { voltage }^{c}\end{array}$ & $\begin{array}{l}\text { External } \\
\text { quantum } \\
\text { efficiency }\end{array}$ & $\begin{array}{l}\text { Current } \\
\text { efficiency }\end{array}$ & $\begin{array}{c}\text { Power } \\
\text { efficiency }\end{array}$ & $\begin{array}{c}\text { CIE } \\
\text { coordinates }\end{array}$ \\
\hline & Doping rate [wt. \%] & {$[\mathrm{nm}]$} & {$[\mathrm{V}]$} & [\%] & {$\left[\mathrm{cd} \mathrm{A}^{-1}\right]$} & {$\left[\operatorname{lm~W} \mathrm{W}^{-1}\right]$} & $(\mathrm{x}, \mathrm{y})$ \\
\hline $\mathbf{A}$ & DPVBi:2a(0.2\%) & $444 / 548$ & 5.2 & 2.7 & 7.0 & 2.3 & $(0.31,0.39)$ \\
\hline B & DPVBi:2b(3.8\%) & $460 / 552$ & 5.3 & 2.5 & 5.5 & 3.3 & $(0.31,0.37)$ \\
\hline C & DPVBi:2b(1.4\%) & $460 / 540$ & 4.6 & 2.8 & 7.0 & 2.4 & $(0.20,0.30)$ \\
\hline D & $\operatorname{DPVBi}: \mathbf{2 b}(1.4 \%)^{\mathrm{b}}$ & $460 / 530$ & 4.8 & 2.3 & 6.3 & 1.9 & $(0.18,0.25)$ \\
\hline
\end{tabular}

${ }^{a}$ Device configurations (thickness): glass//TO/CuPc $(10 \mathrm{~nm}) / \alpha-\mathrm{NPB}(50 \mathrm{~nm}) /$ doped-DPVBi $(50 \mathrm{~nm}) / \mathrm{Alq}_{3}(10 \mathrm{~nm}) / \mathrm{LiF}(1.2 \mathrm{~nm}) / \mathrm{Al}(100 \mathrm{~nm})$; ${ }^{\mathrm{b}} \mathrm{Device}$ configurations (thickness): PET//TO/CuPc (10 nm)/ $\alpha$-NPB $(50 \mathrm{~nm}) / \mathrm{doped-DPVBi}(50 \mathrm{~nm}) / \mathrm{Alq}_{3}(10 \mathrm{~nm}) / \mathrm{LiF}(1.2 \mathrm{~nm}) / \mathrm{Al}(100 \mathrm{~nm}) ;{ }^{\mathrm{C}}$ Turn-on voltage at which emission becomes detectable $\left(\sim 10^{-2} \mathrm{~cd} \cdot \mathrm{m}^{-2}\right)$.b

In order to circumvent this problem, thioxophosphole $\mathbf{2 b}$ (Scheme 1) was then studied as the dopant for the DPVBi matrix since this compound possesses a weak ability to aggregate in the solid state.[6c] Effectively, a doping rate of $3.8 \%$ was necessary to obtain CIE coordinates that are close to white-emission $(0.31,0.37)$. The performance (Table 2$)$ of this WOLED is very satisfying with a brightness of $1158 \mathrm{~cd} \cdot \mathrm{m}^{-2}$ at $20 \mathrm{~mA} / \mathrm{cm}^{2}$. Moreover, the brightness regularly increases with the current density showing the good stability of this WOLED in spite of the rather high doping rate. In this case, the doping rate value to reach white emission is quite easy to control and to reproduce within the co-evaporation process 
compared to the first case. Furthermore, a decrease of the doping rate (1.4\%, Table 2$)$ has an effect on the CIE coordinates $(0.20,0.30)$ but the efficiencies are not modified. The device $\mathbf{C}$ emits a bluish white emission (brightness of $3770 \mathrm{~cd} \cdot \mathrm{m}^{-2}$ at $20 \mathrm{~mA} / \mathrm{cm}^{2}$ ) because the contribution of the emission of DPVBi in the electroluminescence spectrum is increased.

This interesting result prompted us to develop flexible OLEDs since these devices can be used in completely new lighting designs.[8] We kept the structure of the device $\mathbf{C}$ but we changed the glass substrate to poly(ethylene terephthalate) (PET) substrate. The performances of the device $\mathbf{D}$ are very similar to device $\mathbf{C}$. The flexible device $\mathbf{D}$ exhibits a small turn-on voltage $(4.8 \mathrm{~V})$ with current and power efficiencies of $6.3 \mathrm{~cd} \mathrm{~A}^{-1}$ and $1.9 \mathrm{~lm} / \mathrm{W}$, respectively. The CIE coordinates, which are similar to device $\mathbf{C}$, are independent of the driving current. The performance (Table 2) of this flexible device $\mathbf{D}$ is very satisfying with a brightness of $2915 \mathrm{~cd} . \mathrm{m}^{-2}$ at $20 \mathrm{~mA} / \mathrm{cm}^{2}$. All these results demonstrate that phosphole-based emitters can be used for the development of efficient fluorescent OLEDs.

\section{CONCLUSION}

These results show the significant potential of phospholes for applications in optoelectronics and namely for the construction of WOLEDs. The major advantage of the phosphole ring relative to other more traditional heterocyclopentadienes (thiophene, pyrrole) is the presence of a reactive heteroatom. Thus, from a single organophosphorus compound, it is possible to prepare easily a family of new chromophores presenting very different optical and redox properties. In addition, the possibility of achieving coordination chemistry opens up broad prospects including the development of diodes using phosphorescence or the development of biosensors.

\section{EXPERIMENTAL}

Device Fabrication and Characterization: EL devices, based on a multilayer structure have been fabricated onto patterned ITO coated glass substrates from from Xin Yan Technology (sheet resistance $20 \Omega /$ sqr) or ITO coated on PET substrate from Sigma-Aldrich. The organic materials (from Lumtec) are deposited onto the ITO anode by sublimation under high vacuum $\left(<10^{-6}\right.$ Torr $)$ at a rate of $0.2-0.3 \mathrm{~nm} / \mathrm{s}$. The common structure of all the devices is the following: a thin layer (10 nm thick) of copper phtalocyanine ( $\mathrm{CuPc})$ is used as hole injection layer (HIL) and $50 \mathrm{~nm}$ of N,N'-diphenyl-N,N'-bis(1-naphthylphenyl)-1,1'-biphenyl-4,4'diamine ( $\alpha$-NPB) as hole transporting layer (HTL). The emitting layer consists of phosphole derivatives (15 nm). A thin layer of 4,4'-bis(2,2'-diphenylvinyl)biphenyl (DPVBi) (35 nm), a 
commercially available molecule (from Syntec) is used as electron transporting layer (ETL). A thin layer of bathocuproine $(\mathrm{BCP})(10 \mathrm{~nm})$ is used as hole blocking layer. $\mathrm{Alq}_{3}(10 \mathrm{~nm})$ is used as electron transporting layer (ETL). Finally, a cathode consisting of $1.2 \mathrm{~nm}$ of LiF capped with $100 \mathrm{~nm}$ of $\mathrm{Al}$ is deposited onto the organic stack. The entire device is fabricated in the same run without breaking the vacuum. In this study, the thicknesses of the different organic layers were kept constant for all the devices. The active area of the devices defined by the overlap of the ITO anode and the metallic cathode was $0.28 \mathrm{~cm}^{2}$.

The current-voltage-luminance (I-V-L) characteristics of the devices were measured with a regulated power supply (Laboratory Power Supply EA-PS 3032-10B) combined with a multimeter and a $1 \mathrm{~cm}^{2}$ area silicon calibrated photodiode (Hamamatsu). The spectral emission was recorded with a SpectraScan PR650 spectrophotometer. All the measurements were performed at room temperature and at ambient atmosphere with no further encapsulation of devices.

Synthesis of compound $2 \boldsymbol{b}$ : To a THF solution (10 mL) of $\mathrm{Cp}_{2} \mathrm{ZrCl}_{2}(286 \mathrm{mg}, 1.00 \mathrm{mmol})$ and 1-(9,9'-dimethylfluoren-2-yl)-8-(5-methyl-2-thienyl)-1,7-octadiyne 1b (395 mg, 1.00 mmol) was added dropwise ( $c a 1 \mathrm{~min})$, at $-78^{\circ} \mathrm{C}$, a hexane solution of $n$-BuLi $(2.5 \mathrm{M}, 0.8 \mathrm{~mL}$, $2.05 \mathrm{mmol}$ ). The solution was warmed to room temperature, and stirred overnight. To this solution was added, at $-78^{\circ} \mathrm{C}$, freshly distilled $\mathrm{PhPBr}_{2}(0.22 \mathrm{~mL}, 1.05 \mathrm{mmol})$. The solution was allowed to warm to room temperature and stirred for $30 \mathrm{~h}$. The solution was filtered on basic alumina (THF) and the volatile materials were removed under vacuum. The yellow precipitate containing phosphole $\left({ }^{31} \mathrm{P}-\left\{{ }^{1} \mathrm{H}\right\} \mathrm{NMR}\left(80 \mathrm{MHz}, \mathrm{CDCl}_{3}\right): \delta=+13.0\right)$ was dissolved in $\mathrm{CH}_{2} \mathrm{Cl}_{2}(20 \mathrm{~mL})$ and elemental sulfur $(32 \mathrm{mg}, 0.12 \mathrm{mmol})$ was added to this solution. The solution was stirred for 1 day at room temperature and chromatographed on silica gel (eluent: heptane/ethyl acetate, 95/5, v/v, $R \mathrm{f}=0.4$ ). $2 \mathrm{~b}$ was obtained as a yellow orange solid (yield = $70 \%, 0.7 \mathrm{mmol}, 374 \mathrm{mg}$ ). $\mathrm{T}_{\mathrm{TGA} 10 \%}: 365{ }^{\circ} \mathrm{C} .{ }^{1} \mathrm{H} \mathrm{NMR}\left(300 \mathrm{MHz}, \mathrm{CD}_{2} \mathrm{Cl}_{2}\right.$ ): $\delta=7.74$ (ddd, $\left.{ }^{4} J(\mathrm{H}, \mathrm{H})=1.5 \mathrm{~Hz},{ }^{3} J(\mathrm{H}, \mathrm{H})=6.9 \mathrm{~Hz},{ }^{3} J(\mathrm{P}, \mathrm{H})=13.8 \mathrm{~Hz}, 2 \mathrm{H}, H_{\text {ortho }}\right), 7.58\left(\mathrm{~m}, 1 \mathrm{H}, H_{\text {fluorenyl }}\right)$, $7.51\left(\mathrm{~d},{ }^{3} J(\mathrm{H}, \mathrm{H})=7.8 \mathrm{~Hz}, 1 \mathrm{H}, H_{\text {fluorenyl }}\right), 7.41-7.31\left(\mathrm{~m}, 4 \mathrm{H}, 2 H_{\text {meta }}, H_{\text {para }}, H_{\text {fluorenyl }}\right) 7.28$ (s, $\left.1 \mathrm{H}, H_{\text {fluorenyl }}\right) 7.23-7.20\left(\mathrm{~m}, 2 \mathrm{H}, H_{\text {fluorenyl }}\right), 7.16\left(\mathrm{~d}, J(\mathrm{H}, \mathrm{H})=7.8 \mathrm{~Hz}, 1 \mathrm{H}, H_{\text {fluorenyl }}\right) 7.08$ (AB system, $\left.{ }^{3} J(\mathrm{H}, \mathrm{H})=3.6 \mathrm{~Hz}, \Delta \mathrm{v}=150.1 \mathrm{~Hz}, 2 \mathrm{H}, H_{\text {thienyl }}\right), 2.87\left(\mathrm{~m}, 2 \mathrm{H}, \mathrm{C}=\mathrm{CCH}_{2}\right), 2.74(\mathrm{~m}, 2 \mathrm{H}$, $\left.\mathrm{C}=\mathrm{CCH}_{2}\right), 2.38\left(\mathrm{~s}, 3 \mathrm{H}, \mathrm{CH}_{3 \text { thienyl }}\right), 1.64\left(\mathrm{~m}, 4 \mathrm{H}, \mathrm{CH}_{2}\right), 1.29\left(\mathrm{~s}, 6 \mathrm{H}, \mathrm{CH}_{3 \text { fluorenyl }}\right) .{ }^{13} \mathrm{C}$ NMR $(75$ $\mathrm{MHz}, \mathrm{CD}_{2} \mathrm{Cl}_{2}$ ): $\delta=154.3$ (s, $\left.C_{\text {fluorenyl }}\right), 153.9$ (s, $\left.C_{\text {fluorenyl }}\right), 148.9\left(\mathrm{~d},{ }^{2} J(\mathrm{P}, \mathrm{C})=22.1 \mathrm{~Hz}, C_{\beta}\right)$, $143.9\left(\mathrm{~d},{ }^{2} J(\mathrm{P}, \mathrm{C})=22.4 \mathrm{~Hz}, C_{\beta}\right), 142.5\left(\mathrm{~s}, C_{\text {thienyl }}\right), 139.1\left(\mathrm{~s}, C_{\text {fluorenyl }}\right), 139.0\left(\mathrm{~s}, C_{\text {fluorenyl }}\right)$, $133.4\left(\mathrm{~d},{ }^{1} J(\mathrm{P}, \mathrm{C})=82.0 \mathrm{~Hz}, C_{\text {ipso }}\right), 133.3\left(\mathrm{~d},{ }^{2} J(\mathrm{P}, \mathrm{C})=17.1 \mathrm{~Hz}, C_{\text {thienyl }}\right), 132.2\left(\mathrm{~d},{ }^{4} J(\mathrm{P}, \mathrm{C})=\right.$ $\left.2.9 \mathrm{~Hz}, C \mathrm{H}_{\text {para }}\right), 131.8\left(\mathrm{~d},{ }^{2} J(\mathrm{P}, \mathrm{C})=12.3 \mathrm{~Hz}, C_{\text {fluorenyl }}\right), 130.9\left(\mathrm{~d},{ }^{2} J(\mathrm{P}, \mathrm{C})=11.5 \mathrm{~Hz}, C \mathrm{H}_{\text {ortho }}\right)$, 
$130.1\left(\mathrm{~d},{ }^{1} J(\mathrm{P}, \mathrm{C})=72.0 \mathrm{~Hz}, \mathrm{C}_{\alpha}\right), 129.1\left(\mathrm{~d},{ }^{3} J(\mathrm{P}, \mathrm{C})=12.3 \mathrm{~Hz}, C \mathrm{H}_{m e t a}\right), 129.0\left(\mathrm{~d},{ }^{1} J(\mathrm{P}, \mathrm{C})=\right.$ $\left.81.7 \mathrm{~Hz}, \mathrm{C}_{\alpha}\right), 128.6\left(\mathrm{~d},{ }^{4} J(\mathrm{P}, \mathrm{C})=5.7 \mathrm{~Hz}, C \mathrm{H}_{\text {thienyl }}\right), 128.4\left(\mathrm{~d},{ }^{3} J(\mathrm{P}, \mathrm{C})=5.8 \mathrm{~Hz}, C \mathrm{H}_{\text {fluorenyl }}\right)$, 127.8 (s, $C \mathrm{H}_{\text {fluorenyl }}$ ), 127.4 (s, $C \mathrm{H}_{\text {fluorenyl }}$ ), 126.0 (s, $C \mathrm{H}_{\text {thienyl }}$ ), 123.7 (d, ${ }^{3} J(\mathrm{P}, \mathrm{C})=5.5 \mathrm{~Hz}$, $\left.C \mathrm{H}_{\text {fluorenyl }}\right), 123.0$ (s, $\left.C \mathrm{H}_{\text {fluorenyl }}\right), 120.4$ (s, $\left.C \mathrm{H}_{\text {fluorenyl }}\right), 120.0$ (s, $\left.C \mathrm{H}_{\text {fluorenyl }}\right), 47.1$ (s, $C H_{3 \text { fluorenyl }}$ ), $29.3\left(\mathrm{~s}, \mathrm{C}=\mathrm{CCH}_{2}\right), 29.1$ (s, C=CCH $\left.\mathrm{CH}_{2}\right), 27.2\left(\mathrm{~s}, \mathrm{CH}_{3 \text { fluorenyl }}\right), 27.1$ (s, $\left.\mathrm{CH}_{3 \text { fluorenyl }}\right), 23.2\left(\mathrm{~s}, \mathrm{CH}_{2}\right)$, 23.0 (s, $C \mathrm{H}_{2}$ ), 15.4 (s, $C \mathrm{H}_{3 \text { thienyl }}$ ). ${ }^{31} \mathrm{P}$ NMR (121 MHz, $\mathrm{CD}_{2} \mathrm{Cl}_{2}$ ): $\delta=52.5$ (s). HRMS (ESI, $m / z):[\mathrm{M}+\mathrm{H}]^{+}$calcd for $\mathrm{C}_{34} \mathrm{H}_{32} \mathrm{PS}_{2}$, 535.16831; found, 535.1701. Anal. calcd for $\mathrm{C}_{34} \mathrm{H}_{31} \mathrm{PS}_{2}$ : C 76.37 H 5.84 S 11.99; found: C 76.28 H 6.02 S 12.05.

\section{ACKNOWLEDGMENTS}

This work is supported by the Ministère de la Recherche et de l'Enseignement Supérieur, the CNRS, the Région Bretagne, China-French associated international laboratory in "Functional Organophosphorus Materials" and COST CM10302 (SIPS).

\section{REFERENCES}

[1] (a) Skotheims, T. A.; Elsenbaumer, R. L.; Reynolds, J. R. (2 ${ }^{\text {nd }}$ edn.) Handbook of conducting polymers, Dekker, New York, 1998. (b). (c) Müllen, K.; Wegner, G. (eds.) Electronic materials: the oligomer approach. Wiley-VCH, Weinheim, 1998. (d) Cheng, Y.-J.; Yang, S.-H.; Hsu, C.-S. Chem. Rev. 2009, 109, 5868-5923; (e) Usta, H.; Facchetti, A.; Marks, T. J. Acc. Chem. Res. 2011, 44, 501-510.

[2] (a) Roncali, J. Chem. Rev. 1997, 97, 173-206. (b) Hissler, M.; Dyer, P.; Réau R. Coord. Chem. Rev. 2003, 244, 1-44. (c) Mishra, A.; Ma, C.-Q.; Bäuerle, P. Chem. Rev. 2009, 109, 1141-1276.

[3] (a) Salzner, U.; Lagowski, J. B P.; Pickup, G.; Poirier, R. A. Synth. Met. 1998, 96, 177189. (b) Cyranski, M. K.; Krygowski, T. M.; Katritzky, A. R.; Von Ragué Schleyer, P. J. Org. Chem. 2002, 67, 1333-1338.

[4] (a) Schäfer, W.; Schweig, A.; Mathey, F. J. Am. Chem. Soc. 1976, 98, 407-414. (b) Nyulaszi, L. Chem. Rev. 2001, 101, 1229-1246. (c) Mattmann, E.; Mathey, .F.; Sevin, A.; Frison, G. J. Org. Chem. 2002, 67, 1208-1213. (d) Mattmann, E.; Mercier, F.; Ricard, L.; Mathey, F. J. Org. Chem. 2002, 67, 5422-5425. (e) Delaere, D.; Nguyen-Nguyen, P.-T.; Nguyen, M. T Chem. Phys. Lett. 2004, 383, 138-142. (f) Nyulászi, L.; Hollóczki, O.; Lescop, C.; Hissler, M.; Réau, R. Org. Biomol. Chem. 2006, 4, 996-998. 
[5] (a) Deschamps, E.; Ricard, L.; Mathey. F. Angew. Chem. Int. Ed. Engl. 1994, 11, 11581161. (b) Mao, S. S. H.; Tilley T. D. Macromolecules 1997, 30, 5566-5569. (c) Hay, C.; Hissler, M. Fischmeister, C.; Rault-Berthelot, J.; Toupet, L.; Nyulaszi, L.; Réau. R.Chem. Eur. J. 2001, 7(19), 4222-4236. (d) Hay, C.; Fave, C.; Hissler, M.; Rault-Berthelot, J.; Réau. R. Org. Lett. 2003, 19, 3467-3470. (e) Morisaki, Y.; Aiki, Y.; Chujo. Y. Macromolecules 2003, 36, 2594-2597. (f) Fave, C.; Cho, T.-Y.; Hissler, M.; Chen, C.W.; Luh, T.-Y.; Wu, C.-C.; Réau. R. J. Am. Chem. Soc. 2003, 125, 9254-9255. (g) Baumgartner, T.; Neumann, T.;. Wirges. B Angew. Chem. Int. Ed. 2004, 43, 6197-6201. (h) Baumgartner, T.; Bergmans, W.; Karpati, T.; Neumann, T.; Nieger, M.; Nyulaszi. L. Chem. Eur. J. Chem. 2005, 11, 4687-4699. (k) Neumann, T.; Dienes, Y.; Baumgartner T. Org. Lett. 2006, 8, 495-497. (1) Dienes, Y.; Eggenstein, M.; Neumann, T.; Englert, U.; Baumgartner. T. Dalton transactions 2006, 11, 1424-1433. (m) Sasaki, S.; Mori, T.; Yoshifuji M. Heteroatom Chem. 2006, 17, 344-349.

[6] (a). Bouit, P.-A.; Escande, A.; Szűcs, R.; Szieberth, D.; Lescop, C.; Nyulászi, L.; Hissler, M.; Réau R. J. Am. Chem. Soc. 2012, 134, 6524-6257. (b) Chen, H.; Delaunay, W.; Yu, L.; Joly, D.; Wang, Z.; Li, J.; Wang, Z.; Lescop, C.; Tondelier, D.; Geffroy, B.; Duan, Z.; Hissler, M.; Mathey, F.; Réau R. Angew. Chem. Int. Ed. Engl., 2012, 51, 214-217. (c) Joly, D.; Tondelier, D.; Deborde, V.; Delaunay, W.; Thomas, A.; Bhanuprakash, K.; Geffroy, B.; Hissler, M.; Réau R. Adv. Funct. Mater., 2012, 22, 567-576. (d) Berlinguette, C. P.; Thangadurai, V.; Baumgartner, T. J. Am. Chem. Soc. 2011, 133, 17014-17026. (e) Fadhel, O. ; Szieberth, D. ; Deborde, V. ; Lescop, C. ; Nyulaszi, L. ; Hissler, M. ; Réau R. Chem. Eur. J. 2009, 15 4914-4924. (f) Fadhel, O.; Benkö, Z. ; Gras, M. ; Deborde, V.; Joly, D. ; Lescop, C.; Nyulászi, L.; Hissler, M. ; Réau, R. Chem. Eur. J., 2010, 16, 11340-11356. (g) Matano, Y.; Nakashima, M.; Imahori, H. Angew. Chem. Int. Ed. 2009, 48, 4002-4005. (h) Su, H. ; Fadhel, O. ; Yang, C.-J. ; Cho, T.-Y. ; Fave, C.; Hissler, M. ; Wu, C.-C. ; Réau, R. J. Am. Chem. Soc., 2006, 128 983-995. (i) Zhang, L.; Hissler, M.; Bauerle, P.; Lescop, C.; Réau R. Organometallics, 2005, 24, 5369-5376. (j) Fadhel, O. ; Gras, M. ; Lemaitre N. ; Deborde, V. ; Hissler, M ; Geffroy, B. ; Réau, R. Adv. Mater., 2009, 21, 1261-1265.

[7] Geffroy, B.; Lemaitre, N; Lavigne, J.; Denis, C.; Maisse, P.; Raimond, P. Nonlinear Optics and Quantum Optics, 2007, 37, 9-19.

[8] (a) D'Andrade, B. W.;. Forrest, S. R Adv. Mater. 2004, 16, 1585-1595. (b) Kamtekar, K. T.; Monkman, A. P.; Bryce, M. R. Adv. Mater. 2010, 22, 572-582; (c) D’Andrade, B. W. 
Nat. Photonics. 2007, 1, 33-34. (d) Gather, M. C.; Köhnen, A.; Meerholz K. Adv. Mater. 2011, 23, 233-248. 